\title{
Vývoj zatopených obcí od poloviny 15. do poloviny 19. století
}

\section{BOHUMÍR SMUTNÝ}

Klíčová slova: přehled majitelů Bítova, Kníniček a Mušova - polovina 15. až polovina 19. století - zastaralé formy hospodaření v zemědělství

\section{SOUHRN}

Období se zabývá dlouhým vývojovým obdobím, které prodělaly později zatopené obce v souladu s vývojem moravského venkova od doby raného novověku do počátků formování občanské společnosti, život obyvatel ovlivňovalo nevolnictví, poddanství, robotní práce a vrchnostenská správa majitelů panství. Pěstování obilí a chov dobytka byly založeny na málo výkonné zemědělské produkci, kde se uplatňoval již zastaralý trojpolní systém, dostatečné hnojení půdy nemohlo být uskutečněno pro malé ustájení dobytka.

\section{ÚVOD}

Během čtyř století prodělaly později zatopené obce dlouhé vývojové období srovnatelné s celkovým vývojem moravského venkova od doby raného novověku, kde se střídaly jednotlivé epochy modifikované politickými, hospodáŕskými a kulturními obměnami. Po stránce politické a správní zde byla uplatňována patrimoniální správa, nevolnictví až do josefínských reforem s tíživou robotou pro vrchnost a současně poddanství. Základem hospodaření zde bylo feudální vlastnictví půdy a s tím spojené zemědělství, založené na konzervativních výrobních postupech, které bylo nutno změnit. Život poddaného se odehrával v rámci vesnice a panství, dále než do sousední vesnice nebo na sousední panství se poddaný obvykle nedostal. Nejvyšším nadřizeným byla vrchnost zastupovaná vrchnostenskými úředníky v zámecké kanceláři, kam se poddaný mohl dostat jen výjimečně, nebot prostředníkem styku s vrchností byl rychtář. Styk s majitelem prostřednictvím úředníků se každoročně odehrával při výběru naturálních a peněžních dávek určených urbářem, a to ve dvou termínech, připadajících na svátek sv. Jiří a sv. Havla. Feudální velkostatek na vrchnostenské půdě (tzv. dominikál) se již nespoléhal na málo produktivní práci poddaných při robotě a na jejich dávky, ale začal podnikat ve vlastní režii tam, kde to bylo ekonomicky výhodné v dodávkách potravin a surovin i mimo vlastní panství. Pro jižní Moravu to byla např. produkce ryb a ovčí viny, stejně jako obilí pro vzdálené trhy. Rušivým momentem v životě venkova i měst byly válečné konflikty, k nimž došlo v tomto období, zejména zničující důsledky třicetileté války, dále vpád Prusů a Sasů na Moravu v polovině 18. století a napoleonské války se dvěma invazemi armády napoleonské Francie na jižní Moravu. Nebyl to jen vpád neprítele na území a jeho prímé násilí, ale také průtahy vojsk, placení kontribuce, což vše vedlo v době třicetileté války ke sbíhání obyvatel z jejich gruntů. Dosud neměnné poměry na venkově se začaly měnit až od poloviny 18. století v souvislosti s reformami panovníků Marie Terezie a Josefa II., které podstatně zasáhly do života poddaných nejen zrušením nevolnictví a úpravou robotních povinností státem, ale stejně také úpravou náboženských poměrů tolerancí jiného náboženského vyznání. S ohledem na zrušení některých klášterů byla upravena struktura far a škol s povinnou školní docházkou. Stát začal více zasahovat do poměrů na venkově po stránce správní, soudní a hospodářské. Pokrok a změny v tradiční zemědělské výrobě se však ještě v 1. polovině 19. století těžce prosazovaly a prostor pro ně se otevřel až po revoluci roku 1848.

\section{BÍTOV}

Bítov, nejprve ves a potom městečko nad soutokem Dyje se Želetavkou, sídlo stejnojmenného panství ve Znojemském kraji, vyrostlo pod zeměpanským hradem, uvedeným v pramenech poprvé k roku 1046, hodnověrnější pramen uvádí bítovskou provincii k roku 1185. Hrad byl často zastavován králem jako léno, od roku 1498 zde vládl rod Lichtenburků až do roku 1576, kdy byl prodán s panstvím Volfu Štrejnovi ze Švarcenavy, roku 1617 byl prodán Fridrichu Jankovskému z Vlašimi [1]. Městečko pod hradem se poprvé připomíná k roku 1498, kdy je zde uváděna také fara a kostel sv. Václava na levém břehu Želetavky. Dědictvím získal hrad s panstvím roku 1734 rod Daunů a vlastnil tento majetek až do roku 1849. Škola je zde uváděna poprvé k roku 1657 [2].

Klimatické podmínky zde byly vzhledem k vyšší poloze uváděny jako drsné a studené. Největší zásahy do struktury osídlení a hospodaření přinesla třicetiletá válka, kdy řada usedlostí a panství zpustla a musela být osazena později novými usedlíky, nebot jen z osazených gruntů bylo možno získat peníze do pokladny vrchnosti. Soupis půdy za účelem zdanění z roku 1671 (lánový rejstř́k) uvádí zde 21 osedlých, zvláštní usedlostí byl mlýn [3]. Podle Tereziánského katastru se hospodařilo na orné půdě a lukách, obvyklá potažní i pěší robota na panském byla po tři dny v týdnu podle velikosti poddanské usedlosti (rustikál) [4]. Spolehlivé údaje jsou již obsaženy v záznamech stabilního katastru ze 40. let 19. století. V roce 1843 zde žilo 393 obyvatel v 56 domech. Hlavním zaměstnáním obyvatel bylo zemědělství, provozované tradičním neproduktivním trojpolním systémem (úhor, ozim, jař), překážkou zde byl kopcovitý terén. Někteří obyvatelé vedle zemědělství provozovali také řemesla (švec, krejčí, kovář). Choval se zde obvyklý hovězí a jiný dobytek, koně měla jen vrchnost, stejně také stádo zušlechtěných ovcí chovaných pro jemnou vinu na prodej. Voda Želetavky byla využívána dvěma moučnými mlýny, z nichž Dvorní mlýn na úpatí hradu patřil vrchnosti, druhý zvaný Malý měl největší sedlák. Obě části obce podél řeky spojoval dřevěný most. Jarní záplavy škodily přilehlým pozemkům. Největší plochu katastru tvorily lesy patřící vrchnosti, Bítov spojovala s okolním světem okresní komerční silnice vedoucí k hradu, jinak zde byly jen špatně udržované spojovací cesty, sjízdné jen za sucha. Místem pro týdenní trhy bylo město Jemnice. V polovině 19. století byl zde uváděn vrchnostenský pivovar a palírna, dále potašárna a cihelna, výrobky šly do okolí, potaš byla prodávána do Brna a Znojma [5]. 


\section{KNIINIČKY}

Ves Kníničky, ve starších pramenech také uváděná Malé Kuničky (!) na panstvi Veveři v Brněnském kraji, je poprvé písemně uvedena roku 1406 jako součást stejnojmenného zeměpanského hradu na levém břehu Svratky. V 15. století hrad vystřídal jako královská zástava několik majitelů, v roce 1533 došlo k prodeji Janu ml. Rokytskému z Ludanic a dále se zde jako majitelé vystřídali v 16. století Pernštejnové, páni z Lipé a Černohorští z Boskovic, od roku 1573 zde sídlili Lomničtí, a to až do prodeje Tiefenbachům roku 1609. V 17. století zde již byly cizí rody jako Collaltově a Sinzendorfové, roku 1802 se majetek dostal do rukou svob. pánu Vilému Mundymu, manufakturnímu podnikateli, což již bylo znamením nové epochy. Vlastnictví pretendenta švédského trůnu Gustava Vasy bylo krátké a pak roku 1844 přišel jako majitel další podnikatel Jiří Šimon svob. pán Sina, pưvodem řecký bankéř a velkoobchodník, jehož rod zde vydržel až do roku 1849. Ves byla přifařena do Bystrce, kde byla také škola. Ačkoliv se Kníničky nacházely v podhradí, nebyly nejvýznamnější lokalitou veverského panství [6].

Klimatické podmínky zde byly uvedeny jako vlhké a studené. Do struktury osídlení zasáhla třicetiletá válka spolu se švédským vpádem na Moravu a obléháním Brna roku 1645. Přes tuto skutečnost vyjádřenou v lánovém rejstříku z roku 1671 bylo panství hodnoceno jako válkou dosti ušetřené [7]. Podle Tereziánského katastru měla největší rozlohu orná půda a louky, pro majitele pozemků byla stanovena robota na dominikále 3 až 1 den v týdnu podle gruntu [8]. Množství údajů je obsaženo ve stabilním katastru. Ves se nacházela severozápadně od Brna na obou březích Svratky. Roku 1843 zde žilo 371 obyvatel v 65 domech. Obyvatelé se živili převážně zemědělstvím a několika řemesly pro místní potřebu, ostatní nalézali práci jako pomocní dělníci v zemědělstvi a také již v brněnských továrnách. Významný byl pro ves tok řeky Svratky, která $\checkmark$ údolí protínala celý katastr, vytvářela četné meandry a poháněla také místní mlýn. Při vysokém stavu vody byly pozvolna zaplavovány okolní louky, což bylo považováno za výhodné zavlažování. Ves byla spojena s Brnem a hradem Veveři okresní komerční silnicí dlážděnou kamenem, k níž vedl přes řeku postavený dřevěný most. Týdenní trhy byly navštěvovány obyvateli v Brně ve středu a v pátek. Poloha Kníniček nedávala dobré možnosti pro zemědělství, které zde bylo provozováno tradičním zastaralým zpưsobem s třetinou orné pưdy nechávané jako úhor, vyhánění dobytka na pastvu znemožňovalo více hnojit ornou půdu, obdělávanou tradičními nástroji. Vypěstované plodiny byly dobré jakosti a jejich skromné přebytky byly prodávány na trzích [9].

\section{MUŠOV}

Mušov, nejprve ves a poté městečko na panství Mikulov v Brněnském kraji a na levém břehu řeky Dyje, je uveden poprvé v listinách z roku 1270 a 1276, dřívějši údaj z roku 1173 je falzum. Ležel na staré významné obchodní cestě z jihu k Brnu, která překračovala most přes řeku Dyji při ústí př́toků Jihlavy a Svratky do ní. Ves byla střediskem rybářství v krajině bohaté na vodní toky. Roku 1276 byla ves uváděna jako část statku Dolní Kounice, součástí panství Mikulov se stala roku 1332 za Lichtenštejnů, na městečko byla povýšena roku 1570 Kryštofem z Lichtenštejna, jehož rod vlastnil Mušov až do roku 1572, kdy byl jako odúmrt’ darován císařem Maxmiliánem II. Adamovi z Ditrichštejna, jehož rod vlastnil mikulovské panství až do roku 1849 [10]. Farní kostel sv. Leonarda stál již ve 13. století, v 16. století se většina zdejších obyvatel hlásila $\mathrm{k}$ protestantismu a částečně k novokřtěnství [11].

Za třicetileté války fara zanikla a byla obnovena až roku 1761 se stavbou nové budovy, škola byla v Mušově postavena za josefinských reforem, i když se zde vyučovalo již dřive. Urbář z roku 1560 udává počet 39 usedlých rodin, do třicetileté války jejich počet vzrostl. Městečko na rušné cestě mezi Mikulovem a Brnem pocítilo za třicetileté války útrapy, jeho neutěšený stav s pustými usedlostmi zachytil lánový rejstřík z roku 1671 [12] (obr. 1). Podle Tereziánského katastru

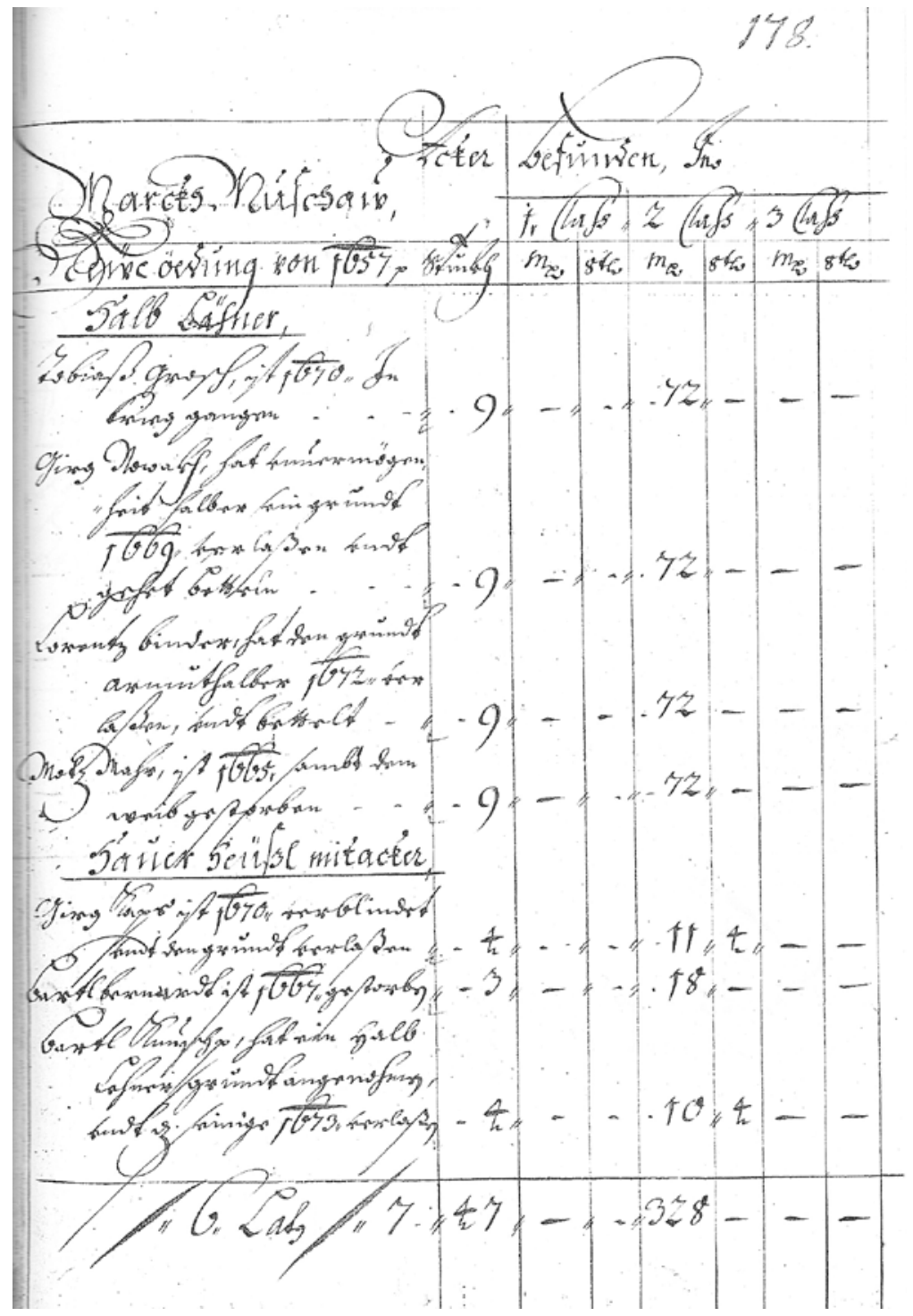

Obr. 1. Nové poustky pololáníků a chalupníků s poli po r. 1657, Lánový rejstřík

Mikulovského panství z r. 1673 (městečko Mušov); D1, inv. č. 138; reprofoto MZA v Brně

Fig. 1. Lahn Register of Mikulov manor from 1673 (town Mušov) (MRA in Brno)

bylo na katastru největší množství orné půdy, dále následovaly louky a pastviny, významnou část pozemků tvořily zde vinohrady. Na mikulovském panství byla stanovena robota v týdnu na 1 den pro sedláky s koňmi, menší vlastníci půdy měli stanovenu pěší robotu na více dní [13]. V roce 1791 bylo v městečku napočítáno 78 domů a 408 obyvatel. Hlavní dopravní cesta byla roku 1727 přestavěna na císařskou silnici na trase z Vídně do Brna, přes Dyji byl postaven dřevěný most v roce 1754, přes rozsáhlé zátopové území vedlo několik dalších mostů [14]. Hodnověrné údaje uvádí stabilní katastr před polovinou 19. století, kdy místní klima bylo hodnoceno jako přiměřeně mírné k řece Dyji, pro bažiny a lesy v okolí jako vlhčí, ale nijak škodlivé pro obyvatele a zvířectvo. Žilo zde roku 1840 celkem 588 obyvatel $\vee 85$ domech. $\vee$ zaměstnání zde převažovalo zemědělství, uváděno je také jen několik řemesel pro místní potřebu. Bylo zde napočítáno 52 koní využívaných $v$ zemědělství i k výdělečnému povoznictví. Chovaný dobytek byl domácího nebo cizího pưvodu, jako např. tažní voli byli z Uher. Podstatnou částí katastru procházely toky tří uvedených řek, jejich malý spád a nízké břehy způsobovaly četné záplavy, ustanovené komise zřízené pro regulaci Dyje zde nemohly bez patřičných financí vytvořit účinná ochranná opatření. Katastrem obce i Mušovem procházela poštovní silnice, udržovaná 
s mostem ve sjízdném stavu s výběrem mýta. Nejbližším tržním místem bylo městečko Dolní Věstonice s týdenními trhy. $V$ hospodaření s půdou byl zachováván trojpolní systém hospodaření, slabě se hnojilo a mělce oralo, jako jinde zde byly překážkou staré zakořeněné zvyky a malá zemědělská osvěta. Přebytky výpěstků, zejména obilí, byly uplatňovány na trzích [15].

Jak možno zjistit z uvedených údajů po čtyři staletí, středobodem každého z výše uvedených katastrů byla řeka, která svým tokem a výškou hladiny po celý rok ovlivňovala život obyvatel a jejich možnosti obživy. Ve všech případech uvedené řeky Dyje a Svratka s prítoky sice způsobovaly povodně a záplavy, na druhé straně ale poskytovaly užitkovou vodu, roztáčely kola mlýnů a pil a poskytovaly možnosti rybolovu. Při srovnání způsobu hospodaření se různil způsob obdělávání půdy Bítova v údolí řeky Dyje a Kníniček v údolí řeky Svratky na jedné straně a Mušova na Dyji v nížinaté oblasti na straně druhé, kde již byly př́znivější půdní a klimatické podmínky pro zemědělství, takže výnosy pěstovaných kultur byly lukrativnější. Lepším možnostem také odpovídaly použivané nástroje v zemědělství. Rovněž zaměstnání obyvatel se poněkud lišilo, i když převážná většina pracovala v zemědělství, u Kníniček je možno zjistit, že část obyvatel nevlastnících půdu nalézala práci v brněnských továrních podnicích již před polovinou 19. století.

\section{Literatura}

[1] DŘíMAL, J. a ŠTARHA, I. (eds.) Znaky a pečeti jihomoravkých měst a městeček. Brno, 1979, s. 346.

[2] HOSÁK, L. Historický mistopis Země moravskoslezské. Praha, 1938, s. 176-178.

[3] MATĚJEK, F. Lánové rejstř̌ky Jihlavského a Znojemského kraje 1671-1678. Praha, 1983, s. 46-47. [4] RADIMSKÝ, J. a TRANTíREK, M. Tereziánský katastr moravský. Praha, 1962, s. 133, 291.

[5] Moravský zemský archiv v Brně, D 8, sign. 1076.

[6] HOSÁK, L., c. d., s. 226-228; ZŘíDKAVESELÝ, F. Kníničky. Dějiny obce 1406-2006, s. 5-23.

[7] MATĚJJEK, F. Lánové rejstř̌ky Brněnského kraje z let 1673-1675. Praha, 1981, s. 91-92.

[8] RADIMSKÝ, J. a TRANTÍREK, M. c. d., s. 291

[9] MZA v Brně, D 8, sign. 1433.

[10] HOSÁK, c. d., s. 246-248; DŘíMAL, J. a ŠTARHA, I. c. d., s. 136.

[11] NEKUDA, V. a kol. (eds) Břeclavsko. Brno, 1969, s. 511-514

[12] MATĚJEK, F. Lánové rejstríky Brněnského kraje, c. d., s. 59-61.

[13] RADIMSKÝ, J. a TRANTÍREK, M. c. d., s. 67, 238.

[14] MZA v Brně, D 8, sign. 1606.

[15] KORDIOVSKÝ, E. (eds.) Mušov 1276-2000. Znojmo, 2000

\section{Autor}

doc. PhDr. Bohumír Smutný, Dr.

凶smutny@mza.cz

Moravský zemský archiv v Brně

Příspěvek prošel lektorským řízením.

\section{DEVELOPMENT OF FLOODED MUNICIPALITIES FROM MID-15 ${ }^{\text {TH }}$ TO MID-19 ${ }^{\text {TH }}$ CENTURY}

\section{SMUTNY, B.}

Moravian Regional Archive in Brno

Keywords: overview of the owners of Bítov, Kníničky and Mušov mid- $15^{\text {th }}$ to mid- $19^{\text {th }}$ century - obsolete forms of farming in agriculture

The period deals with the long development period, which later flooded the municipalities in accordance with the development of the Moravian countryside from the early modern period to the beginnings of the formation of civil society, the life of the inhabitants influenced the serfdom, the subservience, the robot work and the supremacy of the owners of the estate. Growing grain and livestock farming was based on low-performing agricultural production, with an already obsolete three field system, sufficient soil fertilization could not be done for small cattle housing. 